\title{
ANALISIS DAYA DUKUNG LATERAL PILE PANCANG MENGGUNAKAN METODE BROMS DAN SOFTWARE ALLPILE
}

\author{
Okto P. Simamora ${ }^{1}$, Chandra Afriade Siregar ${ }^{2}$ \\ 1,2 Universitas Sangga Buana YPKP \\ ${ }^{2}$ konrespodensi : chandra.afriade@usbypkp.ac.id
}

\begin{abstract}
The foundation is one of the most important parts of the structure. The foundation must be able to withstand and continue the burden of the construction on it as well as the behavior of the soil around the foundation. The foundation carries not only axial loads but also sumbu horizontal loads and working moments. The sumbu horizontal load of the mast foundation can occur due to earthquake force, wind force on the upper structure, ship collision force and others. Therefore, the analysis of the sumbu horizontal carrying capacity of the foundation is important, so that the foundation construction is safe and efficient and can carry the existing sumbu horizontal load.This analysis uses two methods, namely the manual method using the Broms method and the method using allpile software where the results of the analysis emphasize the comparison of the results of both methods.Based on the results of the analysis obtained the sumbu horizontal carrying capacity of a single pile on the broms method is $98,026 \mathrm{kN}$ and the result of Software Allpile is $90,000 \mathrm{kN}$ while on the group pile using the broms method is 105,868 kN and allpile software is 98,300 kN the comparison of both methods on single pile and group piles below $10 \%$.
\end{abstract}

Keywords: Lateral Capacity, Broms Method, Allpile Software

\begin{abstract}
ABSTRAK
Pondasi ialah salah satu bagian struktur yang terutama. Pondasi wajib sanggup menahan serta meneruskan pembebanan dari konstruksi diatasnya pula sikap tanah di dekat pondasi. Pondasi tidak cuma memikul pembebanan aksial tetapi pula pembebanan sumbu horizontal serta momen yang bekerja. Pembebanan sumbu horizontal pondasi pile bisa terjalin akibat pembebanangempa, pembebananangin pada struktur atas, pembebanantumbukan kapal serta lain- lain. Sebab itu, analisis energi dukung sumbu horizontal pondasi ialah perihal yang berarti, supaya konstruksi pondasi nyaman serta efektif dan bisa memikul pembebanan sumbu horizontal yang terdapat.Analisis ini memakai 2 tata cara ialah tata cara manual memakai tata cara Broms serta tata cara memakai Aplikasi ALLPILE dimana hasil analisis lebih menekankan perbandingan hasil dari kedua tata cara. Bersumber pada Hasil analisis diperoleh energi dukung sumbu horizontal pile tunggal pada tata cara broms merupakan 98, $026 \mathrm{kN}$ serta hasil Aplikasi Allpile merupakan 90, $000 \mathrm{kN}$ sedangakan pada pile kelompok memakai tata cara broms merupakan $105,868 \mathrm{kN}$ serta aplikasi allpile merupakan 98, $300 \mathrm{kN}$ perbandingan kedua tata cara pada pile tunggal serta pile kelompok dibawah $10 \%$.
\end{abstract}

Kata Kunci: Daya Dukung Lateral, Metode Broms, Software ALLPILE

\section{PENDAHULUAN}

Pada konstruksi bangunan, pondasi ialah salah satu bagian struktur terutama. Pondasi wajib sanggup menahan serta meneruskan pembebanan dari bangunan struktur diatasnya. Pondasi memikul pembebanan aksial, pula pembebanan sumbu horizontal serta momen yang bekerja. Pembebanan sumbu horizontal serta momen yang bekerja pada pondasi pile bisa terjalin akibat pembebananangin, pembebanangempa pada struktur bangunan atas, pembebanantumbukan yang diberikan kapal serta lain- lain. Oleh sebab itu, analisis energi dukung sumbu horizontal pondasi wajib dicoba sebab sama berartinya dengan analisis energi dukung aksial serta analisis momen yang bekerja, perihal ini dicoba supaya pondasi pada konstruksinyaman serta efektif 
dan bisa memikul pembebanan sumbu horizontal yang terdapat.

Ada bermacam tata cara buat memastikan besarnya energi dukung sesuatu pondasi. Analisis energi dukung sumbu horizontal bisa dicoba dengan menginterpretasi hasil analisis energi dukung sumbu horizontal dengan parameter tanah dari hasil uji lapangan semacam uji SPT.

Riset ini mangulas analisis energi dukung sumbu horizontal pile pancang tunggal serta kelompok dengan 2 tata cara ialah, tata cara Broms setelah itu dicoba perbandingan hasil perhitungan dengan hasil perhitungan memakai aplikasi ALLPILE.

\section{TINJAUAN PUSTAKA}

\section{Umum}

Pada tiap bangunan konstruksi yang berdiri langsung diatas bumi tentunya wajib topang oleh pondasi. Fondasi adalah suatu rekayasa konstruksi yang meneruskan pembebanan bangunan pada tanah, ada 2 perihal yang wajib dicermati, ialah:

1. Energi Dukung Fondasi wajib lebih besar dari pembebanan yang dimiliki struktur bangunan tersebut yang menjadi pembebanan rencana yang bertumpu pada pondasi.

2. Settlement tidak boleh lebih dari penurunan rencana.

\section{Tanah}

Tanah ialah salahsatu material utama dalam mempertahankan bangunan yang ditopang oleh pondasi, pada struktur atas dan pembebanan sendiri pondasinya. Maka pondasi harus mampu menahan tanpa adanya settle pada bangunan. Secara teknis tanah adalah material berupa mineral-mineral ataupun bahan organik yang tidak terikat secara kimia satu dan lainnya [1].

Tanah terdapat 3 campuran, ialah butiran tanah, air serta void. Void dikira tidak mempunyai pengaruh teknis, sedangkan air sangat pengaruhi sifat tanah. Ruang di antara butir-butir tanah bisa terisi oleh air serta/ ataupun void. Apabila rongga tersebut berisi air sepenuhnya, hingga tanah dikatakan dalam keadaan basah air. Apabila rongga tersebut terisi air serta void hingga tanah pada keadaan basah sebagian (partially saturated).

\section{Sifat - Sifat Tanah}

Sifat tanah tergantung lokasi yang berada pada project tertentu. Untuk mengenal jenis tanah dan sifat-sifatnya diperlukan soil investigasi. Ada pula sifat- sifatnya antara lain:

(Permeabilitas (Permeability)

Pengujian ini untuk menghitung bagaimana air dapat terserap pada tanah dalam dekade waktu.

$>$ Kosolidasi (Consolidation)

Konsolidasi dihitung untuk mengenali perubahan void pada tanah sehingga mendapatkan settlement.

$>$ Tegangan geser (Shear Strength)

Untuk menentuan kekuatan tanah/eart pressure terhadap perubahan keruntuhan. yang diperlukan pada pondasi agar tanah stabil. 
Sifat-sifat fisik lainya

Tanah berdasarkan dari 2 bagian, ialah bagian solid serta bagian rongga. Bagian solid berdasarkan dari partikel- partikel solid, sebaliknya bagian void terisi air ataupun void seluruhnya apabila tanah tersebut basah. ataupun kering. Apabila gumpalan tanah tidak seluruhnya dalam keadaan basah (basah), hingga rongga tanah hendak terisi oleh air serta void. Totalitas bagian tersebut bisa nampak dalam diagram fase [2].
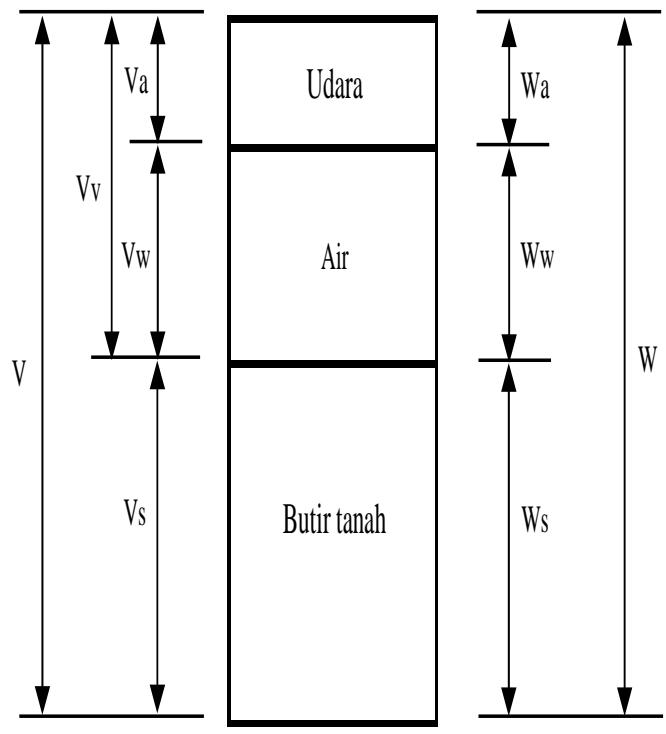

Gambar 1 : Tiga fase elemen tanah

Keterangan :

$\mathrm{V} \quad$ : volume total $=\mathrm{Va}+\mathrm{Vw}+\mathrm{Vs}$

Va : volume udara (dalam bagian void)

Vw: volume air (dalam bagian void)

Vs : volume butir tanah

$\mathrm{Vv}$ : voleme rongga $=\mathrm{Va}+\mathrm{Vw}$

$\mathrm{W}$ : berat total $=\mathrm{Ws}+\mathrm{WW}$

Ws : berat butiran solid

Ww: berat air

Wa : berat udara $=0$

\section{Daya Dukung Tanah}

Energi dukung tanah merupakan keahlian tanah fondasi menahan pembebanan struktur ataupun bangunan di atasnya. Energi dukung tanah dipengaruhi oleh basahnya tanah, kohesi, friksi , tipe tanah serta tegangan wajar tanah.

Energi dukung tanah ini penting untuk menunjang pembebanan strutur dengan mengurangi resiko settle yang melebihi batas maksimal desain pada bangunan. menghadapi penyusutan yang masih terletak dalam batasan batas maksimal.

Energi dukung untimate adalah kekuatan maksimal yang mampu ditahan oleh pondasi sehingga engineer mampu merancang sesuai range tertentu dengan tepat. Energi dukung ultimante ini paling utama sebagai dasar pembebanan pondasi yang dipengaruhi kuat pergeseran tanah serta settle [3].

\section{Metode Broms}

Metode ini memakai list tekanan tanah yang lebih diperkecil dengan menghitung 
kedalaman dan respon tahanan tanah pada angka maksimal. Berikut ini sebagian keuntungan serta kerugian memakai tata cara Broms:

- Metode Broms bisa dipakai untuk short pile dan long pile.

- Metode Broms bisa dipakai keadaan joint atas free dan fixed

- Metode Broms hanya bisa dipakai pada intervace tanah yang berlapis teratur, berkohesi dan non berkohesi.

Dalam tata cara Broms memperhatikan sikap pile ialah antara sikap short pile (kaku) serta panjang (elastis) dan memperhatikan keadaan joint atas pile dalam keadaan joint atas pile leluasa (free head) serta joint atas pile terjepit (fixed head). Dalam riset ini, Fondasi yang dipakai ialah Fondasi long pile (elastis) dengan keadaan joint atas pile leluasa ( free head) [4].

\section{Keadaan Short pile}

1. Joint atas pile bebas (free head) untuk short pile $(\mathrm{L} / \mathrm{T} \leq 2$ atau $\mathrm{R} / \mathrm{T} \leq 2)$ dengan keadaan joint atas pile bebas (freehead), pola perubahan keruntuhan terjadi.

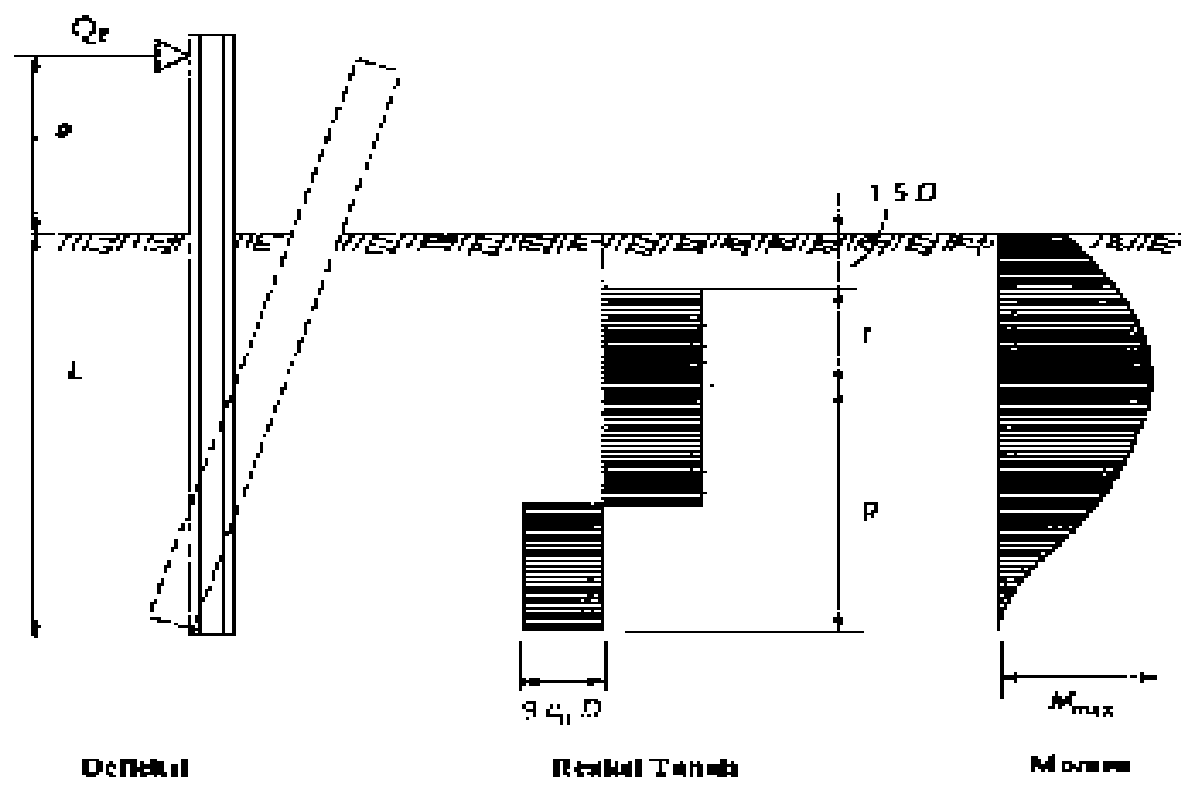

Gambar 2 : Defleksi dan teknis kerja perubahan keruntuhan untuk Fondasi short pile [4]

Dimana Qg adalah pembebanan sumbu horizontal yang bekerja, e adalah panjang pile yang mucul elevasi plus pada tanah, L adalah depth pile terpancang, Gambar 2.2 menunjukkan bahwa tahanan tanah mencapai nilai ultimatenya diseluruh kedalaman pile.

2. Joint atas pile terjepit (Fixed Head)
Teknis kerja perubahan keruntuhan dan pembagian merata dari tahanan tanah untuk short pile dengan

keadaan joint atas pile terjepit (fixedhead atau restrained) yang mungkin terjadi pada tanah berkohesi dapat dilihat pada Gambar 3. 


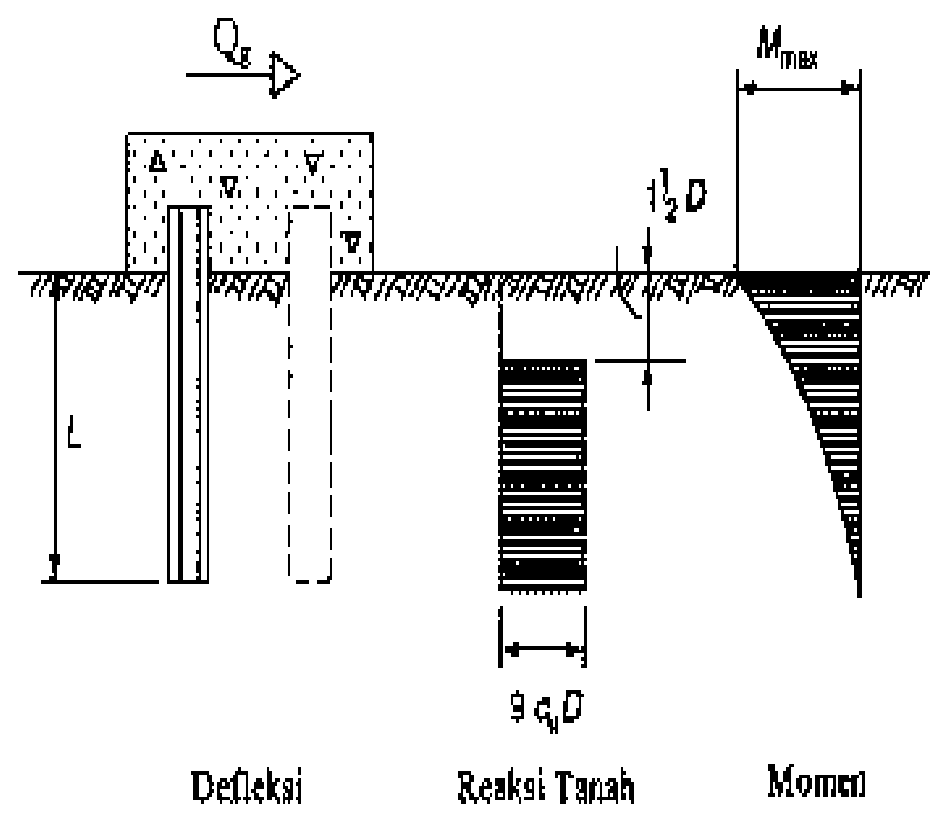

Gambar 3 : Defleksi akibat pembebanan sumbu horizontal [4]

\section{Keadaan Long pile}

1. Joint atas pile bebas (free head)

Untuk Fondasi long pile, teknis kerja perubahan keruntuhan tanah, pembagian merata tahanan tanah serta momen lentur di tunjukkan pada Gambar 2.4. Dari gambar tersebut terlihat bahwa defleksi pile terutama pada dekat bagian atas tanah sehingga respon tanah di bagian bawah pile semakin sedikit, begitu pula besarnya momen dan pembagian meratanya sepanjang pile [5].

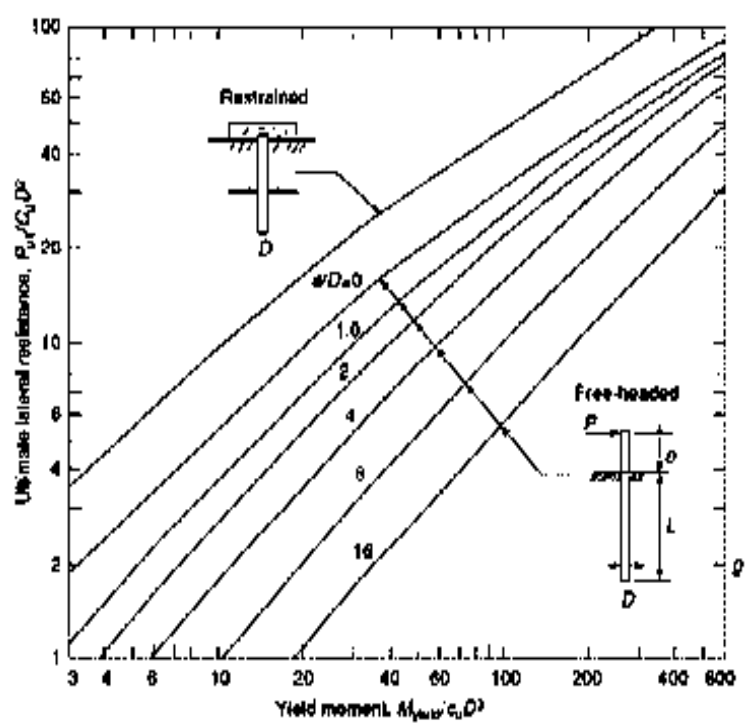

Gambar 4 : Defleksi dan Teknis kerja Perubahan keruntuhan untuk Fondasi Long pile dengan Keadaan Joint atas Pile Bebas Akibat Pembebanan Sumbu horizontal pada Tanah Berkohesi [4]

Untuk tanah berkohesi seperti tanah lempung, pada long pile dengan joint atas pile bebas berlaku persamaan sebagai berikut: 
Tahanan momen

$$
\begin{array}{ll}
\mathrm{W} & =\frac{I_{p}}{(d / 2)} \\
\mathrm{My} & =\sigma_{\mathrm{lt}} \cdot \mathrm{W}
\end{array}
$$

$M m a \mathrm{~S}=H u \cdot(\mathrm{e}+1,5 \cdot B+0,5 \cdot f)$

Dengan mengetahui nilai $\mathrm{Mu} /(\mathrm{Cu}$. B3) maka nilai $\mathrm{Mu} /(\mathrm{Cu} . \mathrm{B2})$ dapat ditentukan dari Gambar 5

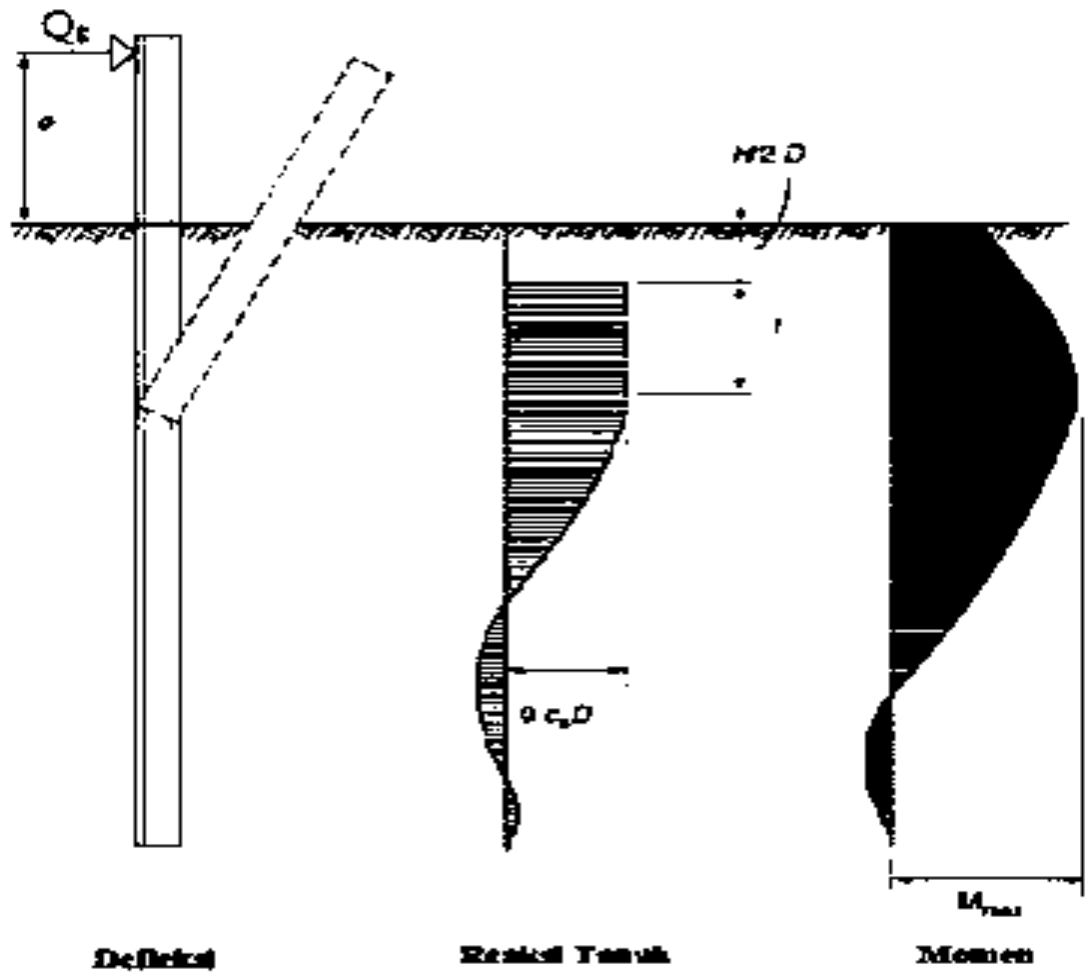

Gambar 5 : Kapasitas pembebanan sumbu horizontal untuk Fondasi long pile pada tanah berkohesi

Pembebanan sumbu horizontal yang ada pada Fondasi long pile adalah sebesar:

$$
H_{u}=\frac{2 M u}{(e+1,5 B+0,5 f)}
$$

2. Joint atas pile terjepit (Fixed Head)

Joint atas pile terjepit biasanya dipakai joint base pada kolom sebuah gedung. secara teknis perubahan keruntuhan, dan pembagian tahanan ultimate tanah, dan momen yang terjadi di pile yang direncanakan untuk keadaan joint atas terjepit pada tanah yang berkohesi dideskripsikan pada Gambar 2.6 berikut ini: 


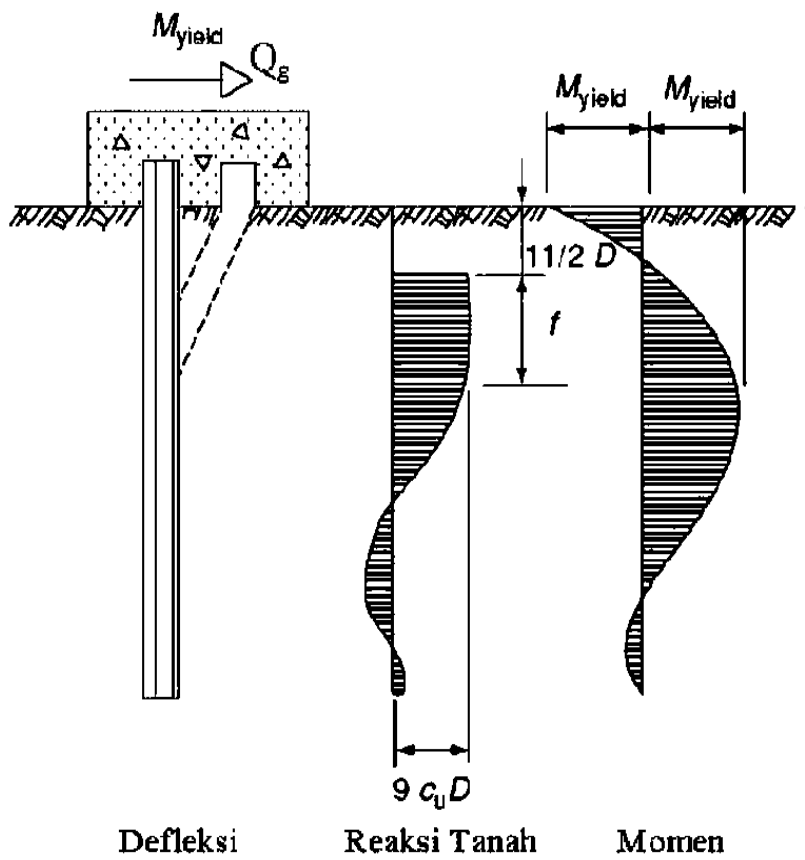

Gambar 6c: Defleksi Akibat Pembebanan Sumbu horizontal untuk Fondasi Long pile dengan Keadaan Joint atas Pile Terjepit pada Tanah Berkohesi [4]

Momen maksimun dan gaya sumbu horizontal ultimate untuk tanah berkohesi dapat dipakai persamaan berikut ini:

$$
H_{u}=\frac{2 \cdot M_{u}}{1,5 \cdot B+0,5 \cdot f}
$$

Dimana:

$$
f=\frac{H_{u}}{9 \cdot C_{u} \cdot B}
$$

\section{Faktor Reduksi Tahanan Tanah}

Dalam menahan bangunan yang pembebanannya besar tidak bisa menggunakan pile tunggal, diperlukan pile kelompok/grup pile. Qa (grup) daya dukung sumbu horizontal grup pile yang berdasarkan dari $\mathrm{n}$ buah pile $Q a($ grup $)=\mathrm{n} \times Q$ (single, $r$ educed $)$, Dimana $Q$ (single, reduced) yaitu efek kekuatan dukungan pada pile tunggal.

\section{Software ALLPILE}

Allpile merupakan program analisis berbasis Windows yang menanggulangi nyaris seluruh tipe pile pancang, tercantum pipa baja, pile$\mathrm{H}$, beton pracetak tumpukan, tumpukan cor auger, poros dibor, tumpukan kayu, tumpukan jetted, tumpukan meruncing, dermaga dengan bel, mikropil (minipile), penaikan jangkar, serta fondasi dangkal.

Salah satu keunggulan utama AllPile dibanding tumpukan yang lain fitur lunak yang mencampurkan sebagian besar analisis tumpukan satu program. Ini menghitung kompresi (dengan penyelesaian), penaikan, serta kapasitas sumbu horizontal seluruhnya. Pengguna cuma butuh menginput informasi sekali, bukan sebagian kali dalam program yang berbeda AllPile membuat analisis pile jadi murah serta efektif waktu.

\section{METODE PENELITIAN}

Alur penataan laporan riset ini dibagi 2 sesi ialah penulis menganalisis energi dukung 
sumbu horizontal memakai Program ALLPILE, serta memakai tata cara Broms. Analisis ini dicoba dengan informasi tanah SPT, pembebananan struktur sama sehingga dikenal korelasi antara 2 tata cara tersebut.

Riset literatur merupakan mencari referensi teori yang relefan dengan permasalahan ataupun kasus yang ditemui. Referensi tersebut berisikan tentang:

- $\quad$ Fondasi

- $\quad$ Analisis tanah (SPT)

- Metode Broms dan program ALLPILE

Referensi ini bisa dicari dari novel, harian, postingan laporan riset serta situs- situs internet yang relefan dengan rumusan permasalahan. Tujuanya merupakan buat memudahkan riset yang dicoba penulis dan selaku bawah teori dalam melaksanakan riset. Dalam sesi ini dicoba pengambilan informasi yang Terletak pada Proyek Pembangunan sarana penyediaan gas buat tenaga mesin gas di Arar Distrik Manyamuk Kabupaten Sorong, Provinsi Papua Barat. Serta informasi yang dibutuhkan dalam penyusunan riset. Informasi tanah yang dipakai dalam analisis ialah informasi SPT ( Standar Penetration Test) serta pembebananan struktur.

Dalam Tugas Akhir ini mangulas topik tentang energi dukung sumbu horizontal memakai 2 tata cara ialah program ALLPILE serta tata cara Broms yang menciptakan parameter tanah dengan tipe fondasi dalam yang didetetapkan selaku tanah homogen dengan parameter tanah serta ukuran fondasi yang di tentukan oleh penulis.

\section{HASIL DAN PEMBAHASAN}

Sehabis meninjau keberlanjutan riset, hingga penulis membenarkan kalau riset yang dicoba merupakan Semacam yang dipaparkan pada diagram alur kalau bahan-bahan yang dipakai wajib melewati proses pengujian.

\section{Data Teknis Pile Pancang}

$>$ Jenis Pile : Pile Pancang Beton

$>$ Bentuk Pile : Lingkaran

$>$ Ukuran Pile : diameter $60 \mathrm{~cm}$

$>$ Panjang Pile : $18 \mathrm{~m}$

$>$ Modulus elastisitas beton: $\mathrm{Ep}=23,5.10^{4}$ $\mathrm{kg} / \mathrm{cm}^{2}$

$>$ Jenis pile : Fixed head (joint atas jepit)

$>$ Mutu Beton (f 'c): $25 \mathrm{Mpa}$

\section{Perhitungan Kekuatan Dukungan}

\section{Sumbu horizontal Pile Pancang}

\section{Metode Broms}

- $\quad$ Modulus Elastisitas Pile pancang (Ep):

$$
\begin{aligned}
& \circ \mathrm{Ep}=4700 \sqrt{f^{\prime} c} \\
& \circ=4700 \sqrt{25} \\
& \circ=23.500 \mathrm{Mpa}=235.000 \mathrm{~kg} / \mathrm{cm}^{2} \\
& \circ \mathrm{Ip}=\left(\frac{1}{64}\right) \pi \mathrm{D}^{4} \\
& \circ=\left(\frac{1}{64}\right) 3,14 .^{4} \\
& \circ=635.850 \mathrm{~cm}^{4}
\end{aligned}
$$

- $\quad$ Modulus Subgrade Horizontal (Kh)

Tabel 1 : Hubungan Nilai $K_{1}$ Terzahgi 


\begin{tabular}{|c|c|c|c|}
\hline Konsistensi & Kaku & Sangat Kaku & Keras \\
\hline $\begin{array}{c}\text { Kohesi Undrained } \\
(\mathrm{Cu}), \mathrm{kN} / \mathrm{m} 2\end{array}$ & $100-200$ & $200-400$ & $>400$ \\
\hline $\mathrm{K} 1, \mathrm{MN} / \mathrm{m} 3$ & $18-36$ & $36-72$ & $>72$ \\
\hline Konsistensi & Kaku & Sangat Kaku & Keras \\
\hline
\end{tabular}

$\mathrm{Kh}=\frac{k 1}{1,5}=\frac{2,7}{1,5}=1,8$

Nilai $\mathrm{k}_{1}$ didapat dari nilai Terzaghi

$\mathrm{K}=1,8 . \mathrm{d}=1,8 \times 60=108 \mathrm{~kg} / \mathrm{cm}^{2}$

$$
\begin{aligned}
& =\sqrt[4]{1.383 .562 .500} \\
& =192,8633 \mathrm{~cm}
\end{aligned}
$$

- Menghitung Kohesi (Cu)

- Kohesi rata - rata pile:

- $\mathrm{Cu}=\sum\left[\mathrm{Cu}^{*} 1_{1}\right] / \sum 1_{1}$

$$
=39.666 \mathrm{kN} / \mathrm{m}^{2}
$$$$
=0,39666 \mathrm{~kg} / \mathrm{cm}^{2}
$$

Tabel 2: Kohesi Rata -rata sepanjang pile

\begin{tabular}{|c|c|c|c|c|c|}
\hline \multirow{2}{*}{ No } & \multicolumn{2}{|c|}{ Kedalaman } & $\mathrm{L}_{1}$ & $\mathrm{Cu}$ & \multirow{2}{*}{$\mathrm{Cu} * l_{1}$} \\
\cline { 2 - 5 } & $\mathrm{Z1}(\mathrm{m})$ & $\mathrm{Z} 2(\mathrm{~m})$ & $(\mathrm{m})$ & $\left(\mathrm{kN} / \mathrm{m}^{2}\right)$ & \\
\hline 1 & 0 & 5 & 5 & 23 & 115 \\
\hline 2 & 5 & 10 & 5 & 30 & 150 \\
\hline 3 & 10 & 15 & 5 & 52 & 260 \\
\hline 4 & 15 & 18 & 3 & 63 & 189 \\
\hline & & $\sum 1_{1}$ & 18 & $\sum \mathrm{Cu}^{*} 1_{1}$ & 714 \\
\hline
\end{tabular}

- Pengkaitan Tipe Pile

$$
\begin{aligned}
\mathrm{B} & =\left(\frac{k h}{4 . E p . I p}\right) \frac{1}{4} \\
& =\left(\frac{1.8 * 60}{4 * 235000 * 635850}\right) \frac{1}{4} \\
& =0.003666
\end{aligned}
$$

\section{(Long pile jenis joint atas terjepit)}

- Short pile

$$
\begin{aligned}
\beta \mathrm{L} & =\leq 0,5 \mathrm{~cm} \\
\beta \mathrm{L} & =0.003666 * 1800 \mathrm{~cm} \\
& =6,5988>0,5 \mathrm{~cm} \text { (tidak memenuhi } \\
& \text { syarat) }
\end{aligned}
$$

- $\quad$ Long pile

$$
\begin{aligned}
& \beta L=\geq 1,5 \mathrm{~cm} \\
& \beta L=0.003666 * 1800 \mathrm{~cm}
\end{aligned}
$$

$$
=6,5988>1,5 \mathrm{~cm} \text { (memenuhi syarat) }
$$

- Tahanan Momen (W)

$$
\begin{aligned}
\mathrm{W} & =\frac{I p}{(d / 2)} \\
& =\frac{635850}{(60 / 2)}=21.195 \mathrm{~cm}^{3}
\end{aligned}
$$

- Momen Ultimate

- $\quad$ My $=25,50$ Ton-m (didapat dari tabel precat pancang perusahaan di indonesia) $=250,069 \mathrm{kN}-\mathrm{m}=2313321 \mathrm{~kg}-\mathrm{cm}$

$$
\begin{aligned}
& \frac{M y}{C u D^{3}}=\frac{2313321}{0,39666 * 60^{3}}=26,99999 \\
& \frac{H u}{C u D^{2}}=21 \text { (Hasil dari grafik) }
\end{aligned}
$$

$$
\begin{aligned}
\mathrm{Hu} & =21\left(\mathrm{Cu} . \mathrm{D}^{2}\right) \\
& =21\left(0,39666 * 60^{2}\right)
\end{aligned}
$$




$$
=29987,496 \mathrm{~kg}
$$

Maka besar gaya sumbu horizontal ijin pile adalah:

$\mathrm{H}_{\mathrm{all}}=\mathrm{Hu} / \mathrm{fs}$

$$
\begin{aligned}
& =29987,496 / 3 \\
= & 9995,832 \mathrm{~kg} \\
= & 98,0256259 \mathrm{kN}
\end{aligned}
$$

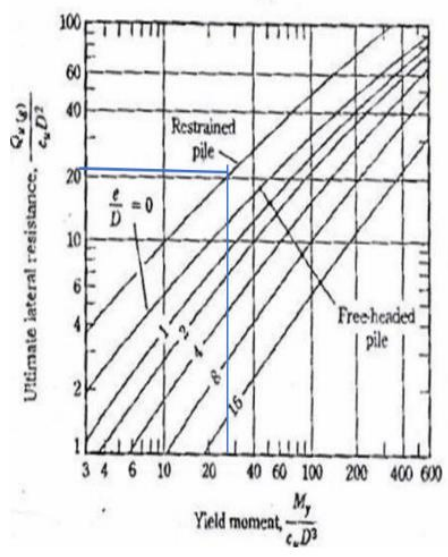

Gambar 8 : Diagram tegangan tanah untuk mencari Hu dan Mmaks ujung jepit

Menghitung Daya Dukung Sumbu horizontal

pile Kelompok

$\frac{s}{d}=\frac{1,5}{0.60}=2,5$

Sehingga dengan grafik didapat faktor reduksi $=0.27$
$H_{\text {group }}=$ Faktor reduksi $\times n \times H_{u}$

$H_{\text {group }}=0,27 \times 4 \times 98.0256259=$

$105,867679 \mathrm{kN}$

\section{Software AllPILE}

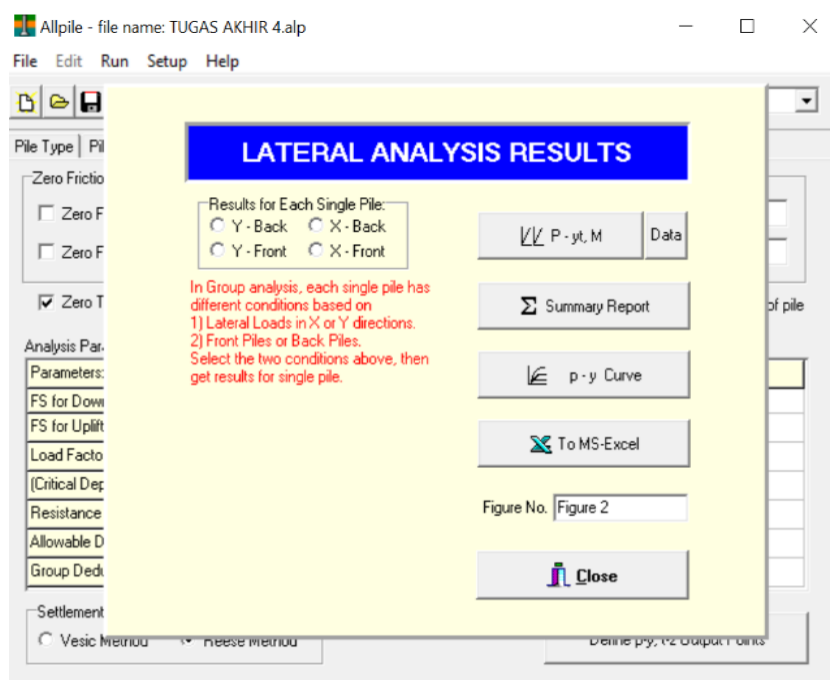

Gambar 4.3 Run Analisys 


\section{Hasil Perhitungan Daya Dukung Sumbu horizontal}

Tabel 1 : Hasil Perbandingan Pile Tunggal

\begin{tabular}{|c|c|c|c|}
\hline No & $\begin{array}{c}\text { Metode Broms } \\
(\mathrm{kN})\end{array}$ & $\begin{array}{c}\text { Sofware } \\
\text { ALLPILE } \\
(\mathrm{kN})\end{array}$ & $\begin{array}{c}\text { Selisih } \\
(\%)\end{array}$ \\
\hline 1 & 98,026 & 90,000 & 7,999 \\
\hline
\end{tabular}

Pada table di atas menunjukan bahwa daya dukung pondasi pile pancang tunggalsecara metode Broms $(\mathrm{kN})$ sebesa $98.026 \mathrm{kN}$ dan dengan metode reese pada software ALLPILE $(\mathrm{kN})$ sebesar 89,999 $\mathrm{kN}$ dengan selisih $7,999 \%$.
1. Hasil perhitungan daya dukungsumbu horizontal pile pancang dengan metode Broms dan software ALLPILE

2. Hasil Perhitungan Daya Dukung Sumbu horizontal Pada Pondasi Pile pancang Group Pile.

Tabel 2 : Tabel Perbandingan Pile Kelompok

\begin{tabular}{|c|c|c|c|}
\hline No & $\begin{array}{c}\text { Metode Broms } \\
(\mathrm{kN})\end{array}$ & $\begin{array}{c}\text { Sofware } \\
\text { ALLPILE } \\
(\mathrm{kN})\end{array}$ & $\begin{array}{c}\text { Selisih } \\
(\%)\end{array}$ \\
\hline 1 & 105,868 & 98,300 & 6,999 \\
\hline
\end{tabular}

Pada table di atas menunjukan bahwa daya dukung pondasi pile pancang group secara metode Broms (kN) sebesa 105,868 kN dan dengan metode reese pada software ALLPILE $(\mathrm{kN})$ sebesar 98,300 kN dengan selisih 6,999\%.

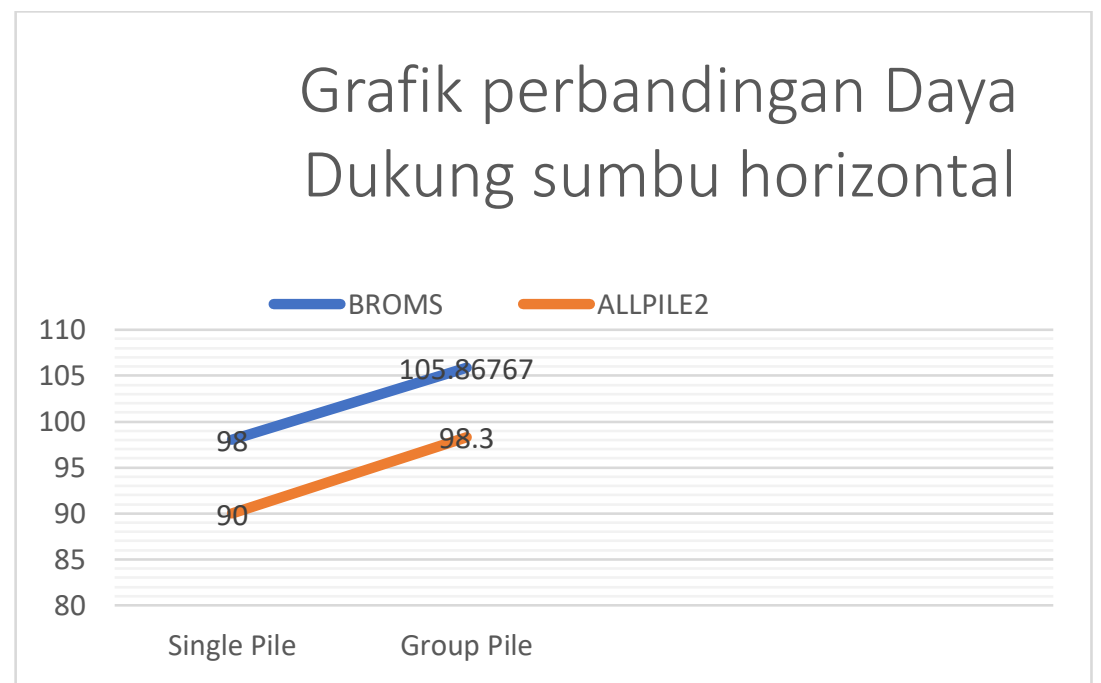

Gambar 9: Perbandingan Daya Dukung Lateral

\section{KESIMPULAN DAN SARAN}

\section{Kesimpulan}

Dari hasil perhitungan riset ini dapat disimpulkan sebagai berikut:

a. Hasil perhitungan dan analisis daya dukung sumbu horizontal Fondasi pile pancang tunggal metode Broms sebesar $98,026 \mathrm{kN}$.

b. Hasil perhitungan dan analisis daya dukung sumbu horizontal pondasi pile 
pancang tunggal menggunakan metode reese pada software ALLPILE sebesar $90,000 \mathrm{kN}$.

c. Hasil perhitungan dan analisis daya dukung sumbu horizontal pondasi pile pancang group pile metode Broms sebesar $105,868 \mathrm{kN}$.

d. Hasil perhitungan dan analisis kekuatan dukungan sumbu horizontal pondasi pile pancang group pile menggunakan metode reese pada software ALLPILE sebesar 98,300 kN.

e. Persentase perbandingan dari perhitungan dan analisis daya dukung sumbu horizontal pada fondasi pile pancang kelompok menggunakan metode Broms dan software ALLPILE dengan perbedaan sebesar 8,999\%.

f. Persentase perbandingan dari hasil perhitungan daya dukung sumbu horizontal fondasi pile pancang tunggal menggunakan metode Broms dengan metode reese pada software ALLPILE dengan perbedaaan sebesar $6,999 \%$.

g. Daya dukung terkecil adalah metode reese dalam sofware ALLPILE sedangkan daya dukung pondasi terbasar adalah menggunakan metode Broms.

h. Perbandingan daya dukung sumbu horizontal pile pancang tunggal dan group pile dibawah $10 \%$.

i. Penggunaan software ALLPILE lebih efesien dibandingkan menggunakan metode broms dalam segi waktu pelaksanaan perhitungan dan perhitungan dengan software ALLPILE dapat mempersingkat waktu pekerjaan.

\section{Saran}

Adapun saran penulis mengenai penelitian ini, sebagai berikut :

a. Peneliti hanya menghitung analisa daya dukung pondasi 1 titik, sebaiknya peneliti menghitung seluruh titik agar mendaptkan hasil yang lebih efektif.

b. Peneliti hanya menghitung pondasi daya dukung sumbu horizontal pada podasi, sebaiknya di hitung semua pembebanan.

c. Peneliti hanya menggunakan 2 metode yaitu metode Broms dan metode reese dalam software ALLPILE.

d. Peneliti tidak menyarakan hasil perhitungan mengunakan software ALLPILE dan metode broms sebagai acuan, disarakan menggunakan metode lain sebagai pembanding.

\section{DAFTAR PUSTAKA}

[1] Siregar, C.A. (2017). Diktat dan Kuliah Mekanika Tanah I (Soil Mechanic I). Bandung: Fakultas Teknik Jurusan Teknik Sipil, Universitas Sangga Buana YPKP.

[2] Bowles, J.E. , 1991, Sifat-sifat Fisis dan Geoteknis Tanah.Jakarta: $\quad$ Erlangga. Brinkgreve, R.B.J., dan P.

[3] Siregar, C.A. (2017). Diktat dan Kuliah Rekayasa Fondasi II (Foundation Engineering II). Bandung: Fakultas Teknik Jurusan Teknik Sipil, Universitas Sangga Buana YPKP. 
[4] Broms, B. 1964. The Sumbu horizontal resistance of Piles in Cohesive Soils. Jurnal of the Soil Mechanics Divisions. ASCE. Vol. 90. No. SM2.

[5] Bowles, Joseph E. 1997. Analisis dan Desiain Pondasi Jilid 1. Jakarta: Erlangga.

[6] Astm. (1999). D2850 - Standard Test Method for Unconsolidated-Undrained Triaxial Compression Test on
Cohesive Soils. Astm D2850, 4 (July 1995)

[7] Bowles, Joseph E. 1997. Arifin, Z., 2008, Analisa Perbandingan Biaya Pelaksanaan Pondasi Pile Pancang dan Pile Bor Pile Jembatan Suramadu, Neutron, Volume 08 , No. 2

[8] Braja M. Das. 1997. Advanced Soil Mechanics. California State University, Sacamento. 